REGIONAL STATISTICS, 2012, VOL. 2: 3-12 DOI: 10.15196/RS02101

WALDO TOBLER

\title{
Looking at Some Data from Isard's "Methods of Regional Analysis"
}

In his path-breaking book "Methods of Regional Analysis" Walter Isard presented several sets of data. Some of these are fictitious, designed to illustrate concepts. Others contain real empirical values. Among the latter are several tables. I have used two of these, not in a research mode, but rather as exploratory visualizations. Of the two matrices one is 36 by 36 in size, the other is 47 by 47 . I have used these tables in their original form without attempting any transformations such as biproportional adjustment to equalize marginals, or eigenvector analysis, or partitioning into symmetric and skew symmetric parts to estimate potentials (Figure 1). Nor have I attempted to reduce the resolution of the data by combining, or by omitting, rows or columns from the matrices.

Figure 1

Net inflows through the Interdistrict Settlement Fund to the New York Federal Reserve Office, June-July 1954

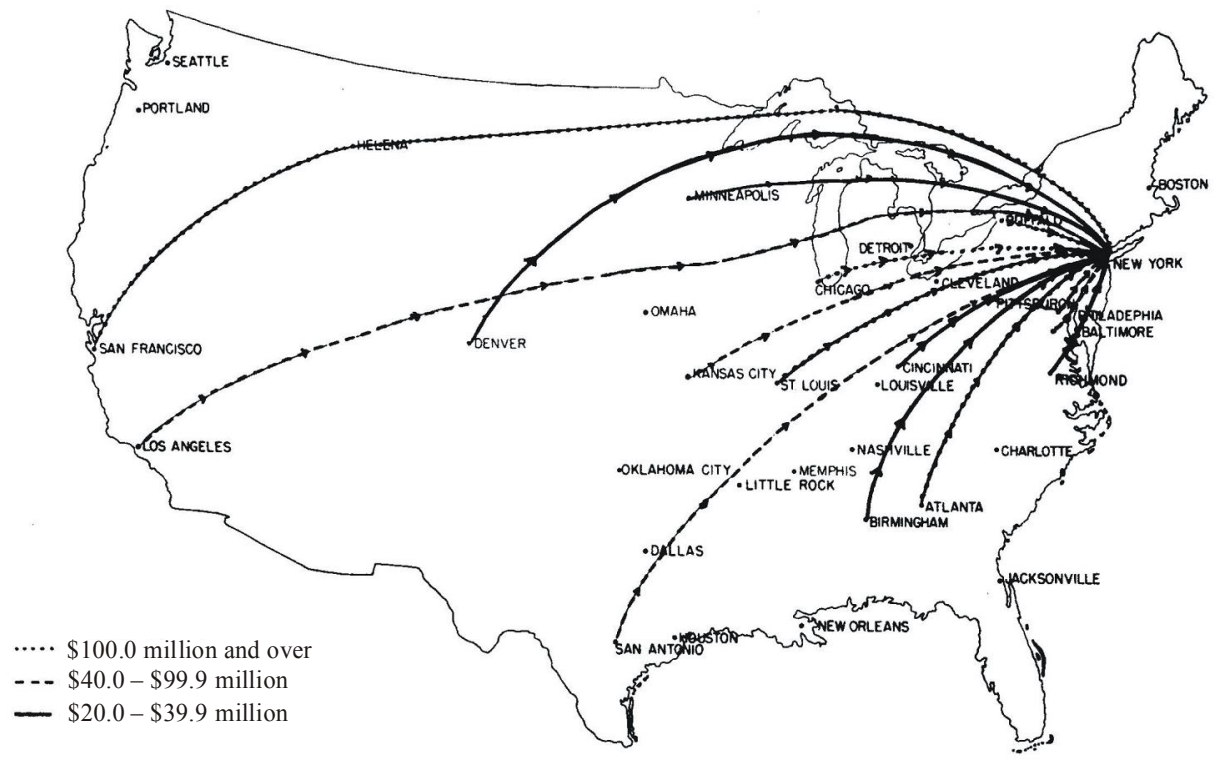

Source: Isard 1960 p. 149. 
Net commercial and financial flows between Federal Reserve zones, week ended October 13, 1954

(Millions of dollars; plus sign indicates net inflow to area at top of column)

\begin{tabular}{|c|c|c|c|c|c|c|c|c|c|c|c|c|c|c|c|c|c|c|}
\hline Towns & $\begin{array}{l}\tilde{0} \\
\text { Dิ } \\
0 \\
0 \\
0\end{array}$ & 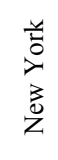 & 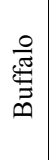 & $\begin{array}{l}\frac{\pi}{\pi} \\
\frac{\pi}{0} \\
\frac{0}{0} \\
\frac{\pi}{2} \\
\frac{\pi}{2}\end{array}$ & $\begin{array}{l}\vec{\Xi} \\
\frac{\vec{J}}{0} \\
\vec{d} \\
\overrightarrow{0}\end{array}$ & 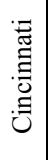 & 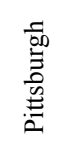 & 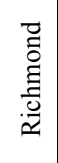 & 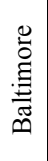 & $\begin{array}{l}\stackrel{0}{0} \\
\stackrel{0}{\Xi} \\
\stackrel{\Xi}{\Xi}\end{array}$ & $\frac{\text { 䒿 }}{\stackrel{\Xi}{*}}$ & 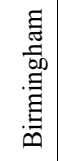 & 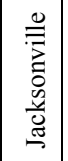 & 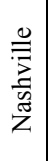 & 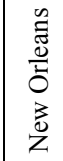 & 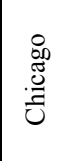 & 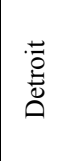 & $\begin{array}{l}\stackrel{n}{\Xi} \\
\stackrel{0}{\Xi} \\
\ddot{\infty}\end{array}$ \\
\hline oston & - & +26 & +1 & +3 & +1 & +1 & +4 & +1 & +1 & +3 & 0 & 0 & +1 & +1 & 0 & +8 & +6 & -1 \\
\hline New York & -26 & - & +3 & -25 & +33 & -3 & +27 & -4 & -6 & +24 & -36 & -19 & +10 & -9 & +19 & +70 & +77 & -66 \\
\hline Buffalo & -1 & -3 & - & 0 & +2 & 0 & +1 & 0 & 0 & 0 & 0 & - & 0 & -1 & 0 & +6 & -3 & 0 \\
\hline Philadelphia & -3 & +25 & 0 & - & -3 & -3 & -6 & -4 & -3 & -4 & -5 & -1 & -2 & -1 & -1 & +7 & -5 & -1 \\
\hline Cleveland & -1 & -33 & -2 & +3 & - & +3 & +5 & +2 & +1 & -1 & -1 & 0 & +1 & +1 & 0 & +10 & -5 & +3 \\
\hline Cincinnati & -1 & +3 & 0 & +3 & -3 & - & -1 & -1 & 0 & 0 & 0 & 0 & 0 & -1 & 0 & +8 & -3 & 0 \\
\hline Pittsburgh & -4 & -27 & -1 & +6 & -5 & +1 & - & -5 & +5 & 0 & -5 & +1 & 0 & +1 & +1 & +7 & +1 & -1 \\
\hline Richmond & -1 & +4 & 0 & +4 & -2 & +1 & +5 & - & +8 & -15 & +6 & 0 & -2 & 0 & 0 & +7 & +3 & +2 \\
\hline Baltimore & -1 & +6 & 0 & +3 & -1 & 0 & -5 & -8 & - & -1 & 0 & 0 & -1 & 0 & 0 & +3 & -1 & 0 \\
\hline Charlotte & -3 & -24 & 0 & +4 & +1 & 0 & 0 & +15 & +1 & - & +9 & +1 & 0 & 0 & 0 & -4 & 0 & +1 \\
\hline Atlanta & 0 & +36 & 0 & +5 & +1 & 0 & +5 & -6 & 0 & -9 & 0 & -6 & -11 & -4 & -12 & +5 & +3 & +2 \\
\hline Birmingham & - & +19 & - & +1 & 0 & 0 & -1 & 0 & 0 & -1 & +6 & - & 0 & -2 & -2 & +1 & 0 & +2 \\
\hline Jacksonville & -1 & -10 & 0 & +2 & -1 & 0 & 0 & +2 & +1 & 0 & +11 & 0 & - & +1 & +1 & -3 & 0 & +1 \\
\hline Nashville & -1 & +9 & +1 & +1 & -1 & +1 & -1 & 0 & 0 & 0 & +4 & +2 & -1 & - & +1 & +1 & 0 & +2 \\
\hline New Orleans & 0 & -19 & 0 & +1 & 0 & 0 & -1 & 0 & 0 & 0 & +12 & +2 & -1 & -1 & - & +5 & +1 & +3 \\
\hline Chicago & -8 & -70 & -6 & -7 & -10 & -8 & -7 & -7 & -3 & +4 & -5 & -1 & +3 & -1 & -5 & - & - & -9 \\
\hline Detroit & -6 & -77 & +3 & +5 & +5 & +3 & -1 & -3 & +1 & 0 & -3 & 0 & 0 & 0 & -1 & - & - & 0 \\
\hline St. Louis & +1 & +66 & 0 & +1 & -3 & 0 & +1 & -2 & 0 & -1 & -2 & -2 & -1 & -2 & -3 & +9 & 0 & - \\
\hline & 0 & -1 & - & 0 & 0 & 0 & 0 & 0 & - & 0 & 0 & - & 0 & 0 & -1 & -1 & 0 & +4 \\
\hline Louisville & -1 & -30 & 0 & 0 & -2 & +3 & 0 & 0 & 0 & -1 & -1 & 0 & -1 & 0 & 0 & +3 & 0 & +9 \\
\hline Memphis & +2 & -11 & - & 0 & 0 & 0 & 0 & 0 & 0 & -7 & 0 & -2 & -1 & -1 & +1 & -1 & +2 & +15 \\
\hline Minneapolis & 0 & +34 & -4 & 0 & -4 & +1 & 0 & +1 & 0 & 0 & 0 & 0 & 0 & 0 & -1 & -15 & +3 & +4 \\
\hline Helena & 0 & -1 & 0 & 0 & 0 & 0 & - & - & - & - & - & 0 & - & - & - & -1 & 0 & 0 \\
\hline Kansas City & 0 & +21 & +2 & +2 & +3 & +1 & -2 & -1 & 0 & 0 & 0 & -1 & 0 & 0 & -1 & +10 & +1 & +5 \\
\hline Denver & -1 & +5 & - & 0 & +1 & 0 & 0 & 0 & 0 & 0 & 0 & - & - & - & +1 & -2 & +1 & +2 \\
\hline Oklahoma City & 0 & +12 & - & +1 & 0 & +1 & +1 & 0 & 0 & 0 & +3 & 0 & - & - & -4 & -21 & 0 & +5 \\
\hline Omaha & 0 & +3 & 0 & 0 & 0 & +1 & 0 & 0 & 0 & 0 & 0 & - & -1 & - & 0 & -1 & 0 & +1 \\
\hline Dallas & -3 & -46 & 0 & 0 & +1 & +2 & 0 & 0 & 0 & 0 & +2 & 0 & -2 & -1 & -3 & +7 & +2 & +10 \\
\hline El Paso & -1 & -1 & - & 0 & 0 & - & - & 0 & - & 0 & - & - & - & - & 0 & +1 & 0 & +1 \\
\hline Houston & -1 & -31 & 0 & -3 & 0 & 0 & -4 & 0 & 0 & 0 & -1 & 0 & -1 & +2 & +4 & +3 & 0 & +1 \\
\hline San Antonio & 0 & +6 & - & +1 & 0 & 0 & 0 & 0 & 0 & 0 & 0 & 0 & 0 & 0 & +1 & +6 & 0 & +1 \\
\hline San Francisco & +14 & -23 & +2 & +1 & -1 & +1 & -4 & -5 & +1 & 0 & -1 & 0 & 0 & 0 & +5 & +22 & 0 & +2 \\
\hline Los Angeles & -3 & +56 & +1 & +2 & +2 & +1 & +1 & +1 & 0 & +1 & -1 & 0 & 0 & 0 & +1 & +15 & +11 & +3 \\
\hline Portland & -1 & +5 & 0 & -3 & 0 & 0 & 0 & -1 & 0 & - & 0 & 0 & 0 & - & 0 & +1 & +1 & -1 \\
\hline Salt Lake City & 0 & -2 & - & 0 & 0 & 0 & 0 & 0 & - & - & - & - & - & - & - & -2 & 0 & +1 \\
\hline Seattle & 0 & +7 & 0 & +1 & 0 & 0 & 0 & 0 & 0 & 0 & 0 & - & 0 & - & - & -2 & +2 & +1 \\
\hline
\end{tabular}

Source: Isard 1960, pp. 152-153.

Note: Careful examination of Isard's table and the maps reveals that they came from different sources and relate to different time periods. Thus the flows mapped here differ from those illustrated in the book. 
Relating to the first of my examples, Isard has four maps of the movement of funds between Federal Reserve cities. These are illustrated on pages 149, 154-156 of the book. $\mathrm{He}$ also presented a table of similar monetary transfers between the thirty-six Federal Reserve cities in the United States (Table 1). Curiously none of the four maps shown is made using the information from this table. But he argued, rightly in my opinion, that such tables and maps should be used more widely. To date I have not seen much evidence that this suggestion has been followed. An examination of recent issues of the Annals of Regional Science convinces one of this fact. Isard thus recognized that insufficient use is often made of the human power of inference from visualizations in research. As an exercise to demonstrate the usefulness of this idea I have used a simple and freely available computer program ${ }^{1}$ (Figure 2 ) to create several maps from the 36 by 36 table. In order to do this it was only necessary to look up the latitudes and longitudes of the cities on the internet and to find a computer compatible outline map of the United States. The preparation of such maps is then very simple and alternate versions of the maps can be created quickly. The computer program allows one to interactively hover (with a mouse) over a location to read its name, and to hover over the flow symbol to be presented with the numerical value. Thus exploratory research use can be made of the maps. This interaction of course is not possible with the printed versions of the maps (Figure 3).

Figure 2

All fiscal transfers during a week (of 1,260 possible)

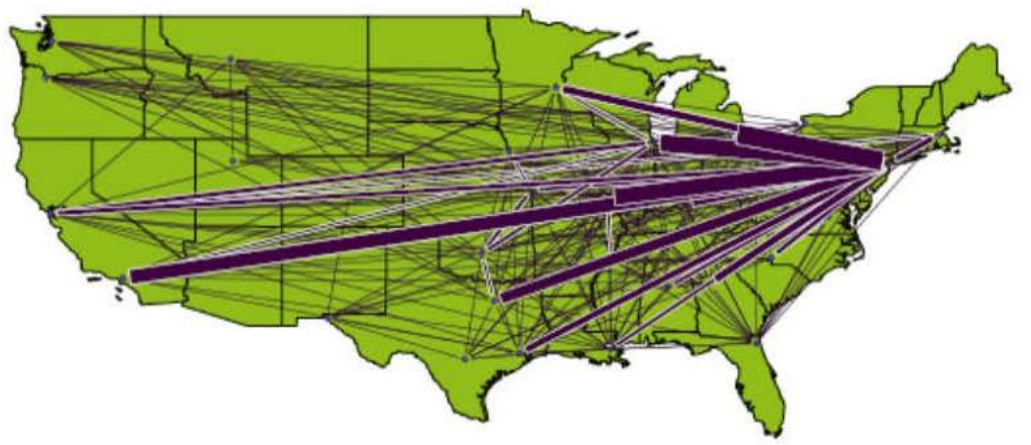

Figure 3

Net transfers greater than $2 * 107$ dollars

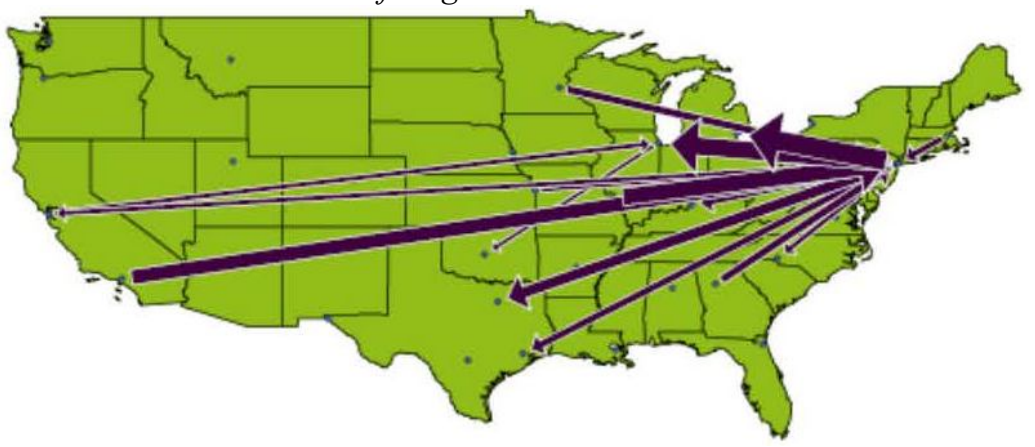

1 http://www.csiss.org/clearinghouse/FlowMapper/ 
The 36 by 36 matrix yields a possible 1,260 movements so that some parsing is desirable. Such tables are not random, but contain considerable structure. The majority of the volume is contained in a minority of the flows so that deleting flows below the mean tends to leave $75 \%$ of the movement volume but requires only $20 \%$ of the movement activity. This is a far better strategy than, for example, reducing the resolution by lumping all of the thirty six cities into the twelve Federal Reserve Districts and thereby reducing the 1,260 values to 132 with the attendant loss of geographic detail.

Examples of maps from one set of data hardly constitutes a research project, but inclusion of such fiscal-movement maps can enhance most studies, and a sequence from several time periods is certain to be enlightening, especially if rendered within an animation.

Figure 4

Above average transfers to New York City

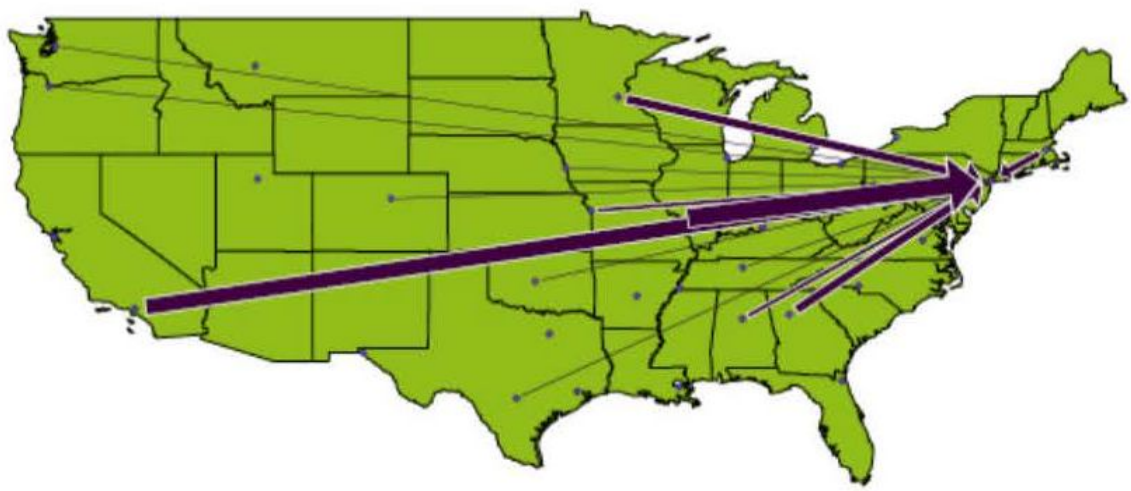

Figure 5 Above average transfers from New York City

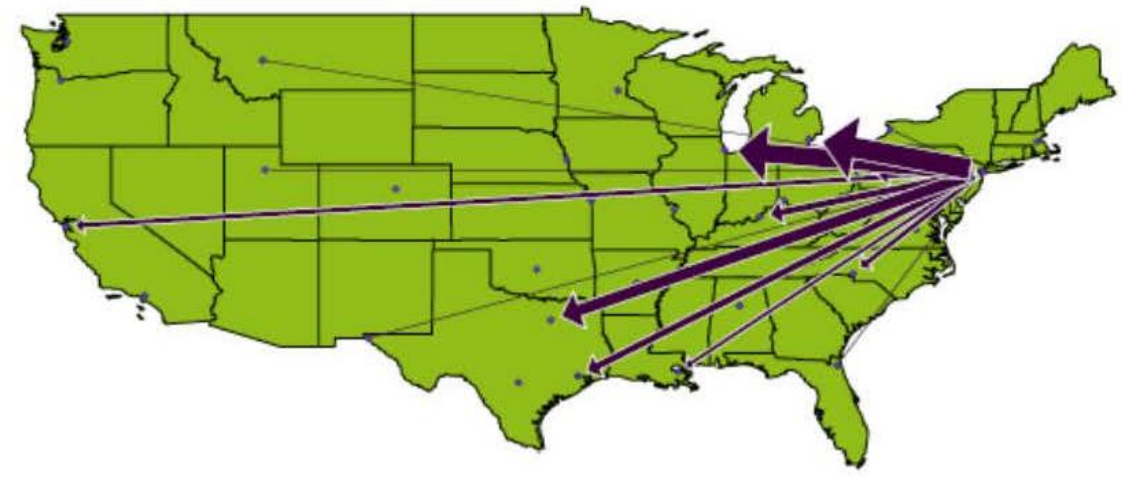

Another important data array is available in an input-output table. As pointed out by Isard "... the interregional input-output approach is most prominent, both in terms of accomplishment and recognition. It represents a fruitful method for depicting and investigating the underlying processes, which bond together the regions of a system and all the separate facets of their economies" (Isard 1960 p. 310.). A graphical exercise, similar to that given above, has been undertaken with respect to the New England 
input/output table from the "Methods" book. In this case there are forty-seven industry groupings and the flows are represented by a 47 by 47 table. The industries are quickly given coordinate locations by a metric multidimensional scaling program (Borgatti 1996). This works somewhat as follows. Consider two industries to be "close" if the quantity of exchanges between them is large. Then construct a diagram in which "close" industries are placed near each other. Do this by positioning a first industry at random. Take the industry "closest" to this and place it on a circle of chosen radius near the first one, thereby establishing a scale for the diagram. The next industry, the third industry, then lies at the intersection of two circles drawn about the first two, with appropriately scaled radii. There is a slight ambiguity and arbitrariness here because two circles can intersect in two places. Choose one of the options and insert the third industry, and then proceed to locate the next (fourth) industry using more circles. The degrees of freedom rapidly decrease and the choices become more difficult. Mathematically the fitting via circles can be replaced by an iterative procedure that places industries into the diagram so that "close" industries are also close in the diagram (see Tobler 1996). The contacts between industries are then drawn as flows between these locations using the same mapping computer program. Curiously, the scaling algorithm has placed most of the industries on the perimeter of a circle with only a few industries in the interior. The suspicion is that the starting configuration, the Gower algorithm was used, began with all items on a circle. The non-metric version, the Torsca algorithm, gave very similar results.

The few interior-lying industries seem to dominate the table. The "Household" category is especially prominent. The important industries exchanging goods and services are easily identified when using the interactive computer program, as are the magnitudes involved. Close visual examination of the original input-output matrix would permit recognition of these major flows, especially when studied by the original compiler of the table. Nevertheless, without such close scrutiny a casual user could find the graphical version(s) more useful and especially rapid. This technique has, to the best of my knowledge, not been used very often, if at all, with input/output tables.

The 47 by 47 matrix could contain as many as 2,162 entries, if the diagonal is ignored, so that a parsing by size is again appropriate, as is seen clearly in the diagrams. Only a little over a dozen entries are significant. As is the case with the movement maps, one example does not constitute a research project but a series of such diagrams, even an animation, can enhance the study of changing regional structure. An opportunity to study regional dynamics thus becomes available. An interesting experiment might be provided by applying the technique to the Leontiev inverse, or to the input/output coefficient matrix. 
New England: input requirements and commodity

\begin{tabular}{|c|c|c|c|c|c|c|c|c|c|c|}
\hline $\begin{array}{l}\text { Industry (Sector) } \\
\text { Purchasing } \\
\text { Industry (Sector) } \\
\text { Producing }\end{array}$ & 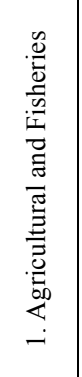 & 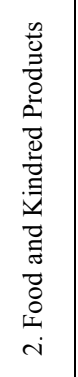 & 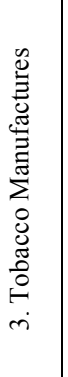 & 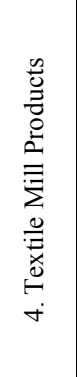 & $\begin{array}{l}\overline{0} \\
\bar{\Xi} \\
\stackrel{2}{0} \\
\text { in }\end{array}$ & 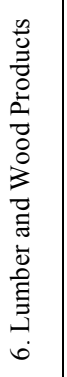 & 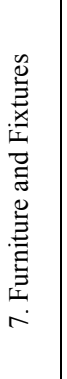 & 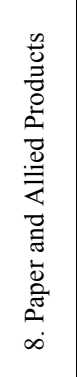 & 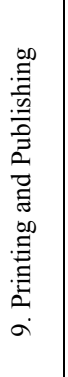 & 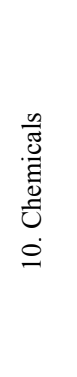 \\
\hline 1. Agriculture and Fisheries & 244.5 & 534.2 & 7.6 & 571.2 & 1.2 & 8.3 & - & 1.2 & - & 57.9 \\
\hline 2. Food and Kindred Products & 53.6 & 174.3 & 0.1 & 16.5 & 0.6 & $*$ & $*$ & 4.1 & $*$ & 32.8 \\
\hline 3. Tobacco Manufactures & - & - & 8.1 & - & - & - & - & - & - & + \\
\hline 4. Textile Mill Products & 1.4 & 0.1 & - & 358.0 & 246.0 & 0.1 & 15.4 & 5.9 & 1.6 & 0.6 \\
\hline 5. Apparel & 1.0 & 7.2 & - & - & 124.2 & - & 0.3 & 2.8 & - & 1.4 \\
\hline 6. Lumber and Wood Products & 3.3 & 2.9 & 0.2 & 4.9 & 0.1 & 47.2 & 20.8 & 36.8 & 0.1 & 2.2 \\
\hline 7. Furniture and Fixtures & - & - & - & 3.3 & - & - & 0.4 & 0.7 & - & - \\
\hline 8. Paper and Allied Products & & 16.1 & 0.6 & 21.4 & 1.6 & 0.2 & 0.8 & 358.0 & 70.3 & 15.8 \\
\hline 9. Printing and Publishing & - & 1.4 & - & 0.6 & - & - & - & - & 49.8 & 0.8 \\
\hline 10. Chemicals & 18.7 & 51.5 & 0.2 & 219.8 & 9.0 & 1.1 & 3.4 & 25.2 & 6.3 & 127.0 \\
\hline $\begin{array}{l}\text { 11. Products of Petroleum and } \\
\text { Coal }\end{array}$ & 10.3 & 2.1 & $*$ & 8.2 & 0.3 & 3.2 & 0.1 & 8.7 & 0.2 & 15.5 \\
\hline 12. Rubber Products & 2.7 & 0.3 & - & 3.6 & 1.1 & 0.4 & 0.3 & 1.2 & 0.2 & + \\
\hline 13. Leather and Leather Products & - & - & - & 0.6 & 3.4 & 0.2 & 0.4 & - & 0.3 & - \\
\hline $\begin{array}{l}\text { 14. Stone, Clay and Class } \\
\text { Products }\end{array}$ & 1.5 & 9.0 & - & 0.3 & - & 0.6 & 1.8 & 3.9 & - & 12.3 \\
\hline 15. Iron and Steel & 0.1 & 0.1 & - & - & 0.1 & 0.4 & 5.2 & - & - & 0.2 \\
\hline 16. Nonferrous Metals & - & - & - & - & - & 0.1 & 0.9 & - & 0.9 & 9.0 \\
\hline $\begin{array}{l}\text { 17. Plumbing and Heating } \\
\text { Supplies }\end{array}$ & - & - & - & - & - & - & - & - & - & - \\
\hline $\begin{array}{l}\text { 18. Fabricates Structural Metal } \\
\text { Products }\end{array}$ & - & - & - & - & - & - & 0.3 & - & - & - \\
\hline $\begin{array}{l}\text { 19. Other Fabricated Metal } \\
\text { Products }\end{array}$ & 1.9 & 19.3 & 0.1 & $*$ & 0.4 & 1.5 & 7.1 & 2.3 & 0.1 & 6.2 \\
\hline $\begin{array}{l}\text { 20. Agricultural, Mining and } \\
\text { Construction Machinery }\end{array}$ & 1.3 & - & - & - & - & - & - & - & - & - \\
\hline 21. Metalworking Machinery & - & - & - & - & - & - & - & - & - & - \\
\hline $\begin{array}{l}\text { 22. Other Machinery (except } \\
\text { electric) }\end{array}$ & - & 0.5 & - & 9.6 & 1.3 & 0.6 & 0.6 & 1.9 & 2.3 & + \\
\hline 23. Motors and Generators & - & - & - & - & - & - & - & - & - & - \\
\hline 24. Radios & - & - & - & - & - & - & - & - & - & - \\
\hline 25. Other Electrical Machinery & - & - & - & - & - & - & - & - & - & + \\
\hline 26. Motor Vehicles & 2.5 & 0.1 & - & - & - & + & - & - & - & - \\
\hline $\begin{array}{l}\text { 27. Other Transportation } \\
\text { Equipment }\end{array}$ & 0.2 & -1 & - & - & -1 & -1 & -1 & $*$ & -1 & + \\
\hline
\end{tabular}




\begin{tabular}{|c|c|c|c|c|c|c|c|c|c|c|}
\hline $\begin{array}{l}\text { Industry (Sector) } \\
\text { Producing }\end{array}$ & 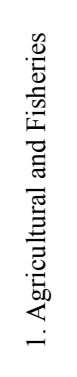 & 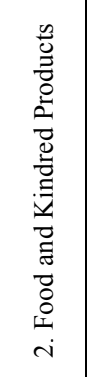 & 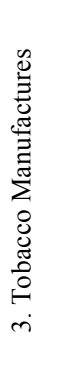 & 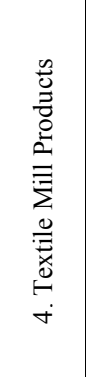 & $\begin{array}{l}\bar{\Xi} \\
\bar{\Xi} \\
\stackrel{0}{0} \\
\text { i }\end{array}$ & 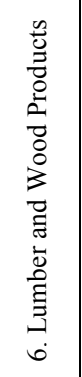 & 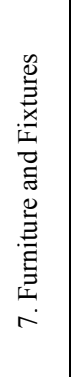 & 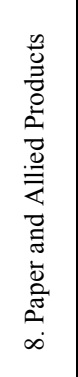 & 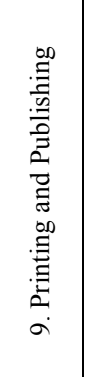 & 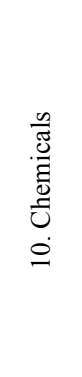 \\
\hline $\begin{array}{l}\text { 28. Professional and Scientific } \\
\text { Equipment }\end{array}$ & - & - & - & - & - & - & 0.1 & 0.8 & 2.1 & 0.6 \\
\hline 29. Miscellaneous Manufacturing & 0.1 & 0.4 & - & 1.1 & 16.2 & $*$ & 0.9 & 2.1 & - & 1.4 \\
\hline 30. Coal, Gas and Electric Power & 1.4 & 6.9 & + & 28.8 & 2.3 & 1.0 & 1.0 & 17.0 & 1.9 & 9.0 \\
\hline 31. Railroad Transportation & 9.9 & 19.5 & 0.2 & 25.8 & 3.8 & 6.2 & 2.9 & 30.9 & 4.4 & 13.7 \\
\hline 32. Ocean Transportation & 1.6 & 4.5 & + & 3.6 & 0.7 & 0.4 & $*$ & 2.2 & $*$ & 2.1 \\
\hline 33. Other Transportation & 12.5 & 13.0 & 0.2 & 21.7 & 1.6 & 6.0 & 2.2 & 16.1 & 1.6 & 4.5 \\
\hline 34. Trade & 30.6 & 14.8 & 0.4 & 62.6 & 23.4 & 2.6 & 3.2 & 24.3 & 2.0 & 8.3 \\
\hline 35. Communications & + & 1.5 & + & 2.5 & 1.2 & 0.4 & 0.3 & 1.1 & 2.5 & 1.1 \\
\hline 36. Finance and Insurance & 5.4 & 5.1 & + & 5.5 & 1.5 & 3.3 & 1.0 & 2.5 & 1.5 & 0.9 \\
\hline 37. Rental & 53.9 & 3.2 & - & 6.9 & 6.1 & 0.8 & 0.9 & 3.6 & 4.0 & 1.6 \\
\hline 38. Business Services & 0.2 & 18.9 & 1.0 & 19.5 & 6.1 & 0.8 & 3.1 & 3.0 & 3.8 & 20.3 \\
\hline 39. Personal and Repair Services & 8.3 & 4.2 & $*$ & 0.8 & 0.2 & 1.8 & 0.2 & 0.6 & 1.3 & 0.5 \\
\hline $\begin{array}{l}\text { 40. Medical, Educational and } \\
\text { Nonprofit Organizations }\end{array}$ & - & - & - & - & - & - & - & - & - & - \\
\hline 41. Amusements & - & - & - & - & - & - & - & - & - & - \\
\hline $\begin{array}{l}\text { 42. Scrap and Miscellaneous } \\
\text { Industries }\end{array}$ & - & - & - & 6.6 & - & - & - & 34.5 & - & 5.3 \\
\hline 43. Undistributed & - & 73.1 & 1.3 & 120.3 & 83.0 & 38.0 & 17.7 & 27.7 & 39.6 & 83.2 \\
\hline 44. Eating and Drinking Places & - & - & - & - & - & - & - & - & 0.1 & - \\
\hline $\begin{array}{l}\text { 45. New Construction and } \\
\text { Maintenance }\end{array}$ & 4.5 & 4.2 & + & 10.7 & 1.0 & 0.5 & 0.4 & 5.8 & 1.0 & 1.7 \\
\hline 46. Government & 18.3 & 40.3 & 1.0 & 175.6 & 23.8 & 14.6 & 6.0 & 68.5 & 21.8 & 36.5 \\
\hline 47. Households & 431.7 & 222.3 & 3.8 & 902.8 & 254.3 & 110.6 & 57.3 & 297.9 & 197.2 & 164.1 \\
\hline Total Gross Outlays & 921.5 & 1250.7 & 25.0 & 2612.9 & 814.6 & 251.1 & 154.9 & 991.4 & 416.8 & 636.9 \\
\hline
\end{tabular}

Source: Isard 1960 pp. 604-607. (Also see the discussion of the data in the table on pages 603-617.) 
The complete I/O table in graphic form

Figure 6

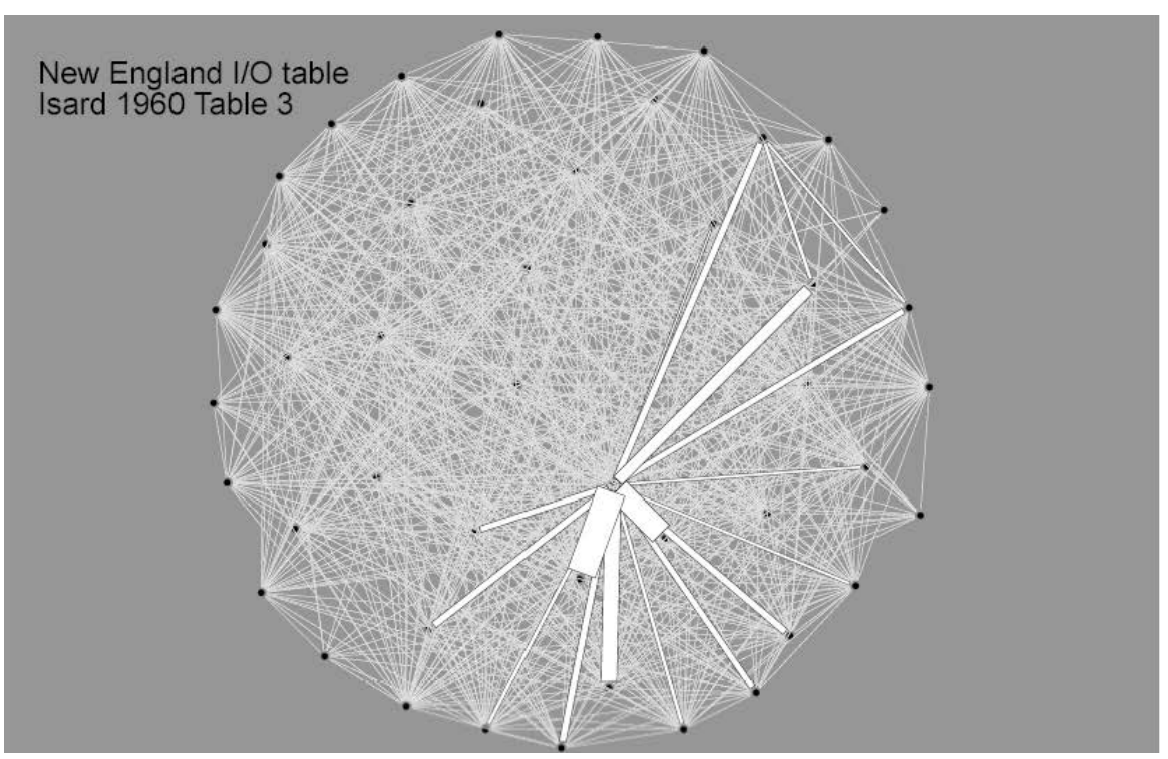

All exchanges above the average

Figure 7

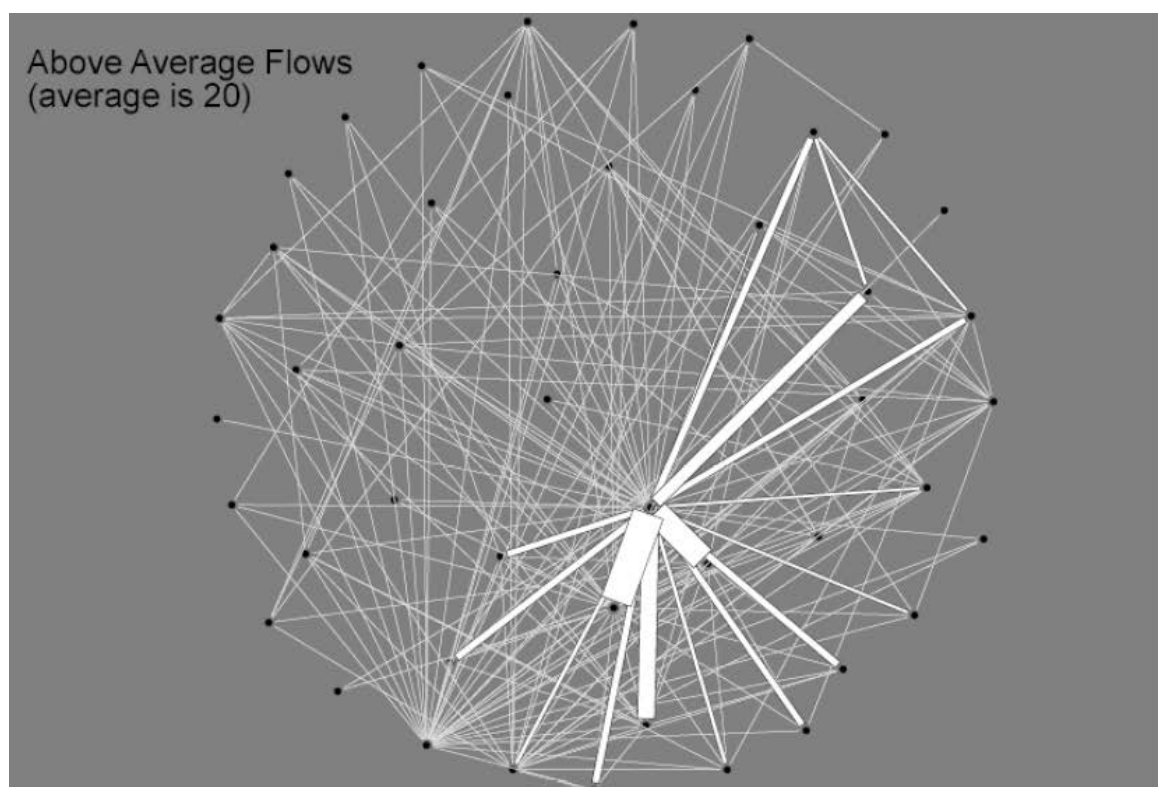




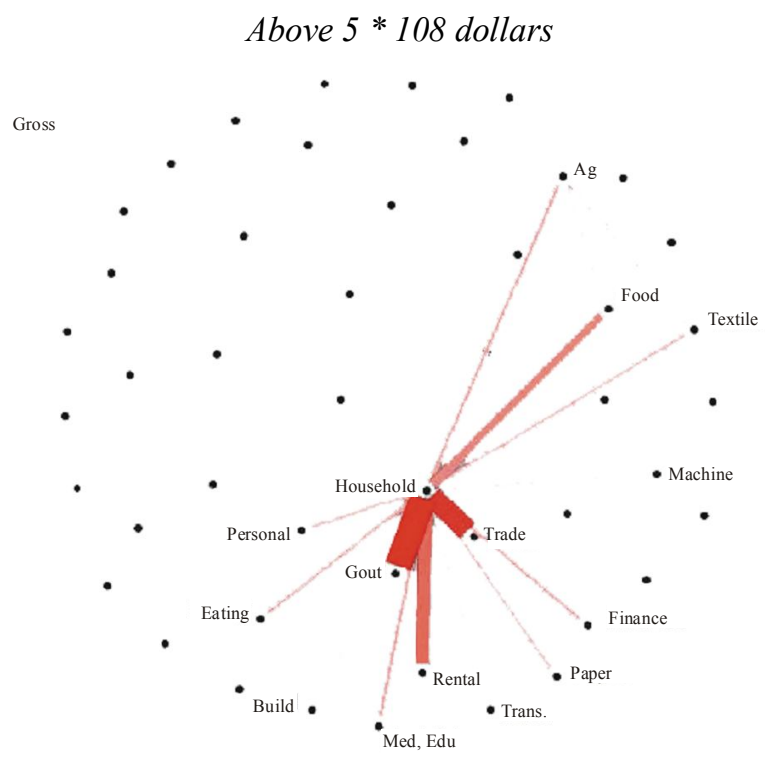

Figure 8

Net exchanges above $2 * 107$ dollars

Figure 9

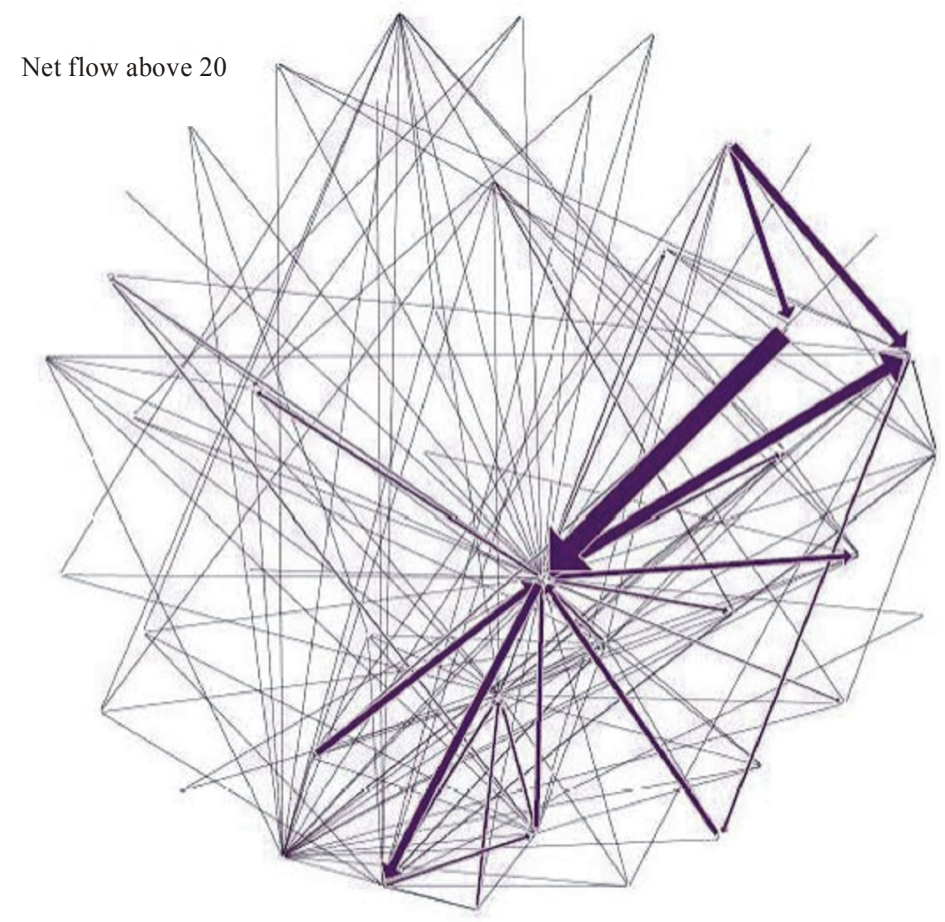


REFERENCES

Tobler, W. (2005): Using Asymmetry to Estimate Potential. Solstice 16 (2) http://wwwpersonal.umich.edu/ copyrght/image/solstice/win05/Sunbelt\%20XXV\%20talk\%20ed.pdf

Isard, W. (1960): Methods of Regional Analysis. MIT Press, Cambridge.

Tobler, W. (1981): A Model of Geographic Movement. Geographical Analysis 13 (1) 1-20.

Borgatti, S. P. (1996): ANTHROPAC 4.0. Analytic Technologies. Natick, Mass.

Tobler, W. (1996): A Graphical Introduction to Survey Adjustment. Cartographica 32 (1) 33-42.

Keywords: monetary flow, input-output tables, visualization.

Abstract

Isard has argued for greater presentation of empirical data in regional studies by displaying tables and geographical maps. In this note his suggestion is followed by displaying two sets of computer maps using tables given in his classic 1960s book. 